\title{
COGNITIVE SEMANTICS ANALYSIS OF ANIMAL PROVERBS IN TOBA LANGUAGE
}

\author{
Elza Leyli Lisnora Saragih ${ }^{1}$, Mulyadi ${ }^{2}$ \\ ${ }^{1}$ Universitas HKBP Nommensen Medan, Indonesia \\ Jalan Sutomo No. 4 A Medan, North Sumatera, Indonesia \\ ${ }^{2}$ Universitas Sumatera Utara, Indonesia \\ Jalan Abdul Hakim No. 1 P. Bulan Medan, North Sumatera, Indonesia \\ Corresponding Author: elzalisnora@gmail.com
}

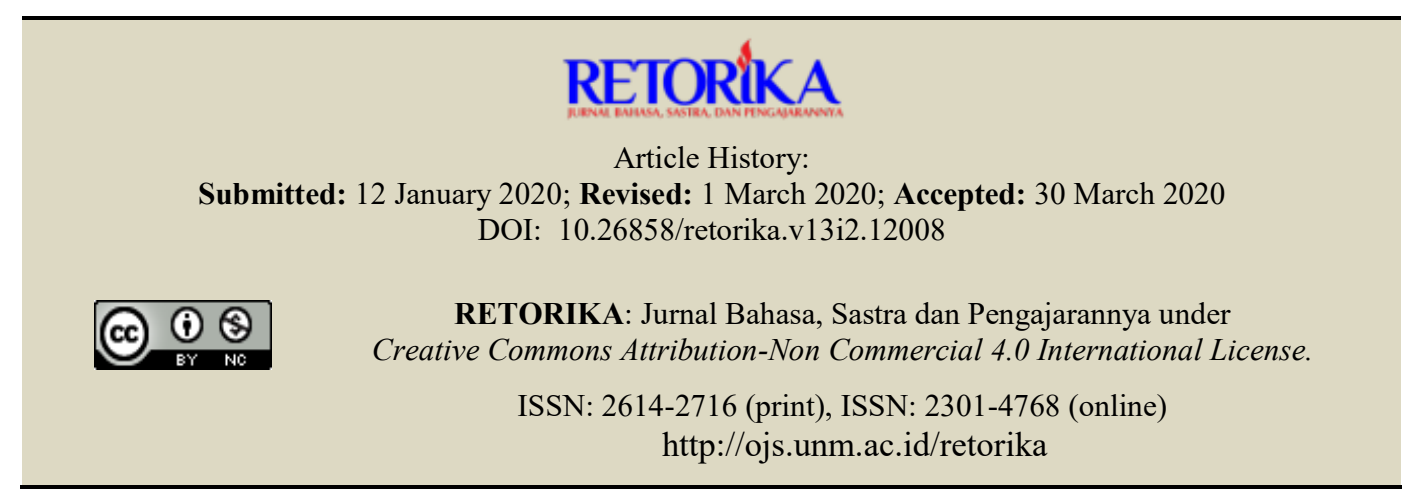

\begin{abstract}
This cognitive semantics study analyzed animal proverbs in Batak Toba language. Descriptive qualitative methods were employed in this study. Preliminary research data were collected from the Umpama and Umapasa Collection of Batak Toba languages written by Richard Sinaga. All proverbs were listened to and grouped by recording and selecting the existing data. In the analysis process, the researchers conducted interpretation method. In addition, the researcher conducted interviews with three Toba native speakers including the researcher himself, and a Batak-Toba linguist. The results showed that there was 33 lexicon used in Toba Batak proverbs. The animal lexicon consists of mammals, birds, insects, fish, and amphibians. The conceptualization of the animals is both positive and negative. The use of animal in the Toba Batak proverbs not only aims to convey ideas or ideas but can also describe the perceptions, experiences and daily life depictions of the Toba Batak people.
\end{abstract}

Keywords: animals, proverb, Batak Toba, cognitive semantics

Proverbs study is a complex and interdisciplinary study. This study is often associated with local culture and literature. In history, proverbs have existed and been used by people for generations from thousands of years ago. Proverbs have become a part of community tradition. This can be seen from the procedures for implementing the customs and rituals of our society which are loaded with the use of proverbs.

Omar (2008) states that proverbs are manifestations of a number of factors including how humans view their surroundings, how people gain experience in their daily lives and also the accumulation of the many experiences inherited by their ancestors and the norms of life combined with religion and culture. In the proverb contained the character and behavior of the community owner when expressing various advice, truth, description of cases or events that occur in the community itself. This proverb is used by the wearer as an effort to utilize the wealth of language to cause certain effects in the ideas they 
convey. In addition, proverbs are also used as heirs of local cultural values transmitted from generation to generation.

Referring to the above statement, it can be said that proverbs are a reflection of the cognition of the speaker's community that results from what is experienced, seen, and observed from their environment. Cognition that is meant here is in accordance with the statement of Lakof and Turner (1989) which states that in forming proverbs, people's cognition refers to natural and universal knowledge so as to give rise to the similarity of concepts from various proverbs that exist in the world. For example, proverbs Time is money (English proverbs), waktu adalah uang (Indonesian proverbs), or like mother like son (English proverbs) and dang dao tubis tubu sian bona na (Batak Toba proverbs).

Research on proverbs has been carried out both in the local languages or foreign languages. Of the many studies, research in the Toba Batak proverb is still not widely chosen. Therefore, a study of this matter needs to be done. The results of this study are expected to add insight and treasure to the wealth of science in the field of cognitive semantics.

Some of the results of studies that have been conducted include Nesa (2013) suggesting that the Persian proverb uses more animal lexicons than English proverbs. Chairani (2016) conducted a semantic cognitive study in proverbs using limbs and a recent study was conducted by Kinkin and Anita (2019) who conducted a study of plant metaphors in Indonesian proverbs.

Lakoff \& Turner (1989) explained that there are several concepts in our minds about animals. How we see, think and use cultural knowledge and experience forms a metaphorical scheme for these animals. Like lions are courageous and noble animals, foxes are clever animals, dogs are loyal animals, wolves are cruel animals, and pigs are dirty and barbaric animals. Krikmann (2007) in his research shows that the use of the name of the animal most often found in proverbs is that animals can be farmed and animals that are docile

Abdullah (2011) in his research results using cognitive semantic studies explained that in Malay proverbs, dogs are conceptualized as animals that are despicable, weak and evil. The results of this study are different from the opinion of Lakoff and Turner (1989) which states that dogs are loyal animals. Sameer (2016) in his research compared proverbs related to dogs and horses in English and Arabic. The results showed that dogs and horses in English and Arabic have the same concepts, social values, and mental processes. Both languages conceptualize horses as something noble, while dogs as something bad and messy. Furthermore Rahardian (2018) explained that in Indonesian proverb tigers are conceptualized as superior animals and are associated with humans who are powerful, strong, rich, meritorious, and brave.

Kridalaksana (2009) states that proverbs consist of thimbles, proverbs, parables or similes, and slogan. The proverb is one type of proverb that contains advice and teachings from parents (Soedjito, 1992: 110; Waridah, 2014: 364). A parable is one type of proverb that compares something with another. Usually the purpose of the parable is different from the group of words that make up it. In general, parables use compa-rative words, like, like, like, for example (Sudrajat, 2008; Soedjito, 1992: 111; Waridah, 2014) Parables are usually used to describe an abstract thing with a concrete thing in daily life.

Sihombing (1997: 15) says that 'proverbs' and 'pantun' are part of the Toba-Batak expression. These forms are very important in every traditional ceremony performed by the community and is still used today. For the Toba Batak tribe, the expression of both umpasa and umpama is a description of various types of social norms that function as social control tools so that people do not deviate from the norms that have been passed down from the previous generation to the next generation.

Various studies on proverbs have been carried out. One approach that can be used is cognitive semantic studies. Lyons (1995: 97) mentions that cognitive refers to the causal relationship between language and mind. Further-more Saeed (1999: 299) states that cognitive semantics are approaches in semantics that view the meaning of language as part of mental problems. Lakoff and Johnson (2003: 3) state that metaphors reflect what is experienced, felt, and thought that happens in real human life. Furthermore Lakoff breaks down cognition into two types, namely cognition obtained by a person through personal experience and cognition obta-ined through culture. For example, an understanding of feeling is 
surely obtained by someone through personal experience. We can deduce the sweet, bitter, sour and spicy taste because it tastes through the tongue. Unlike the case with understanding of wild animals. This understanding is not always obtained through personal experience. The understanding that wolf animals are wild and easily provoked is not necessarily through individual experience. This understanding can arise as a result of previous community experiences about wolves conceptualized for generations. This understanding is structured in cognition, thus giving rise to the concept that wolves are wild animals.

From these examples, it can be understood that cognitive semantics examines the relationship between concepts, structures, representations of meaning, and human experience. Evans and Green (2006: 48) mention that cognitive semantics is the study of the relationship between conceptual systems, semantic structures, and human experiences that are realized by language. Gardenfors (1999) states that cognitive semantics are related to mental representation and its relationship to language. That is, lexical meaning is conceptual. In other words, the meaning of the lexeme does not refer to the real-world entity in question, but to a concept based on thought based on experience with that relation or entity.

Metaphors are an important part of cognitive semantic studies. Metaphor is the process of mapping two domains, namely mapping the source domain into the target domain. This mapping process is a process of associating the target domain and the source domain is obtained based on the experience experienced by someone (Evans \& Green, 2006)

Nirmala (2012) states that in producing metaphorical expressions humans are able to use their creativity in choosing and determining what concepts will be chosen and conceptualization of what will be done and can further explain how cognitive processes occur when metaphorical expressions are produced. Linguistic metaphor theory holds that a metaphor must consist of three basic elements, namely tenor, vehicle, and ground. Taylor (2003: 135) explains the three basic elements of the metaphor, among others, the tenor or target domain (pebanding) is the concept or object described, discussed, imagined, symbolized, or compared. The target domain is also referred to as a receptor. Vehicle or source domain (comparison) is a concept that describes or denotes or symbolizes the tenor or target domain. Source domains are also referred to as "donors".

In this sense the vehicle or source domain is the symbol or figure of speech itself. Ground (sense or equality) is the relation of equality between the tenor or target domain and the vehicle or source domain. The relation of this equation can be in the form of objective equations such as form, nature, or a combination of them, emotive equation, concept equation, function and sociocultural equality.

\section{METHOD}

This study discusses the Toba Batak proverbs that are sourced from animals by using cognitive semantic studies. Cognitive semantics considers that meaning is part of mental problems. One important study in cognitive semantics is metaphor. Metaphor is seen as an important element in the human thought process that is united in language. Metaphor is considered as a type of conceptualization of human experience that never escapes any use of natural language (Siregar, 2004).

The method used in this research is descriptive qualitative research. Descriptive research is research carried out solely based on facts or phenomena that are indeed empirically alive to its speakers so that the resulting language is the same as portraits or in the form of paparanyang as is (Sudaryanto, 2008: 62).

The object of study in this study is the Toba Batak proverb. Sihombing (1989: 15) says that 'proverbs' and 'pantun' are part of the Toba Batak language expression. These forms are very important in every traditional ceremony performed by the community and is still used today. Preliminary data were obtained from a collection of examples and umapasa of the Toba Batak language written by Richard Sinaga. Furthermore, the methods and techniques of data collection use the method of listening. All proverbs are listened to, grouped by recording and selecting existing data. The aim is to obtain accurate and specific data. In addition, interviews were also conducted with three original speakers including the researcher himself, and Toba Batak linguists. The aim is to understand the social and cultural aspects of the community of Toba Batak speakers. 
Furthermore, the data are analyzed in accordance with the theory previously described. In the process of analysis, the researcher con-ducted the method of interpretation.

\section{FINDINGS AND DISCUSSION}

\section{Findings}

Based on the analysis that has been done, there were 5 groups of animal metaphor usage in the Toba Batak language. The intended animal groups include groups of birds, mammals, pisees or fish, amphibians and insects.

Table 1. Data on the Use of Animal Metaphors InToba Batak Proverbs

\begin{tabular}{llcc}
\hline & Kinds & Amount & $\%$ \\
\hline 1. & Birds & 9 & $27 \%$ \\
2. & Mammals & 16 & $47 \%$ \\
3. & Fish & 3 & $10 \%$ \\
4. & Amphibian & 1 & $3 \%$ \\
5. & Insects & 4 & $13 \%$ \\
\hline
\end{tabular}

The table above shows that in the Batak Toba proverbs the metaphor of mammals is dominant, followed by the use of birds, insects, fish and amphibians. In addition, there is also a saying that comes from animal body parts such as wings, legs, tails, ears and horns.

\section{Proverbs about Mammals}

The use of the mammalian lexicon is the dominant form used in the Toba Batak proverb. Based on the results of the research, found mammal species used in the Toba Batak proverbs such as asu 'dog', babi 'pigs', bodat 'monkeys', bagudung 'mice', horbo 'buffalo', gaja 'elephants', hoda 'horses', lobbu 'ox' and huting 'cat' with positive or negative metaphor. Proverbs that use the mammal lexicon include: (1) Horbo mardugu, bojak akka lisat 'Buffalo collides, frog tramples'; (2) Dang loja horbo pausung-usung tandukna 'Not tired of carrying a buffalo the horn'; (3) Situlluk matani horbo 'Piercing buffalo eyes'; (4) Malum-malum boti songon bugang nihorbo jalang 'Heal like a wild buffalo wound'; (5) Songon hehean lobbu, dung ditogu mangalo 'Like the nature of an ox, after being helped against'; (6) Diorong asu do na soampuna 'Barking dog that is not its master'; (7) Agoan asu do halak na hurang dena 'Someone will lose a dog if not dili-gently calling him'; (8) Boru si babi jalang 'Wild boar girl'; (9) Dang bolas dua babiat sarura 'There can't be two tigers in one valley'; (10) Haru bagudung molo sai nijukjukan olo mangharat 'Whereas the mouse if stabbed and kept on the hole will bite too'; (11) Dolgi ranggas diinganani bodat, ngali aek diingani dekke 'Comfortable, trees are occupied by monkeys, cool water occupied by fish'; (12) Holong-holong bodat 'Affection like a monkey'; (13) Manggagat hambing in ari udan 'Eating goats on a rainy day'; (14) Songon Parange ni huting 'Like the nature of a cat'; (15) Dapot ursa dibaen bogasna, dapot imbo dibahen soarana 'Got a deer because of the trail, get a monkey because of his voice'.

\section{Horbo (Buffalo)}

In the proverb Batak Toba horbo (buffalo) is a conceptualization of a leader or someone who is strong and never tired. In this case, horbo is a positive conceptualization. This can be seen in the following proverbs:

(1) Horbo mardugu, bojak akka lisat

'Buffalo collide, frog trampled'

Meaning: When leaders fight then the people suffer

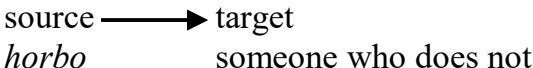
tired of doing something profession

(2) Ndang loja horbo pausung-usung tandukna horn

'Not tired of the buffalo carrying its

Meaning: Someone who does not feel tired of doing something work in accordance with his talent

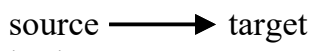

horbo someone who does not tired of doing something profession

\section{Asu (Dog)}

Asu (dog) is a conceptualization of a loyal person. The use of $a s u(\operatorname{dog})$ can be seen in the following proverbs: 
(3) Diorong asu do na soampuna

'Barking dog that is not its master'

Meaning: Someone who interfere which is none of his business will get a reaction

$\begin{array}{ll}\text { source } \longrightarrow & \text { target } \\ \text { Asu } & \text { someone loyal protect } \\ \text { his employer }\end{array}$

It is also found that the conceptualization of asu (dog) as property or belonging to it. This can be seen in the following proverbs:

(4) Agoan asu do halak na hurang dena 'Someone will lose a dog if not diligently calling him'

Meaning: Someone who does not take care, pay attention or less care about his property, then hers will come loose lost

source $\longrightarrow$ target

Asu possessions

\section{Babi (Pig)}

The babi lexicon is a conceptualization of someone who is despicable and does not maintain his honor. Here is a proverb that uses pig lexicon:

(5) Boru si babi jalang

'Wild boar girl'

Meaning: Someone or a girl who sells his honor

$\begin{array}{ll}\begin{array}{l}\text { source } \longrightarrow \\ \text { babi }\end{array} & \begin{array}{l}\text { target } \\ \text { someone who des } \\ \text { pises/sells honor }\end{array}\end{array}$

\section{Babiat (Tiger)}

The lexicon babiat (tiger) is conceptualized to a strong, powerful leader. This can be seen in the following proverbs:

(6) Dang bolas dua babiat sarura

'There can't be two tigers in one valley'

Meaning: It is not possible two leader in one place or two inner rulers one country

$\begin{array}{ll}\text { source } \longrightarrow & \text { target } \\ \text { babiat } & \text { leader/ruler }\end{array}$

\section{Bagudung (Mouse)}

Lexical bagudung (rat) is a conceptualization of people who are weak and have no strength. The following proverb is meant:

(7) Haru bagudung molo sai nijukjukan olo mangharat
'Whereas the mouse if stabbed and kept on the hole will bite too'

Meaning: If you continue to be hurt or bullied, weak people or peo ple poor will fight

source $\longrightarrow$ target

bagudung weak people

\section{Bodat (Monkey)}

Lexicon bodat (monkey) is a conceptualization of someone who does not want to change, stupid and innocent. Following the proverb:

(8) Dolgi ranggas diinganani bodat, ngali aek diingani dekke

'Comfortable, trees are occupied by monkey's, cool water occupied by fish'

Meaning: Someone who is comfortable and don't want to hange from the situation

$\begin{array}{ll}\begin{array}{l}\text { source } \longrightarrow \\ \text { bodat }\end{array} & \begin{array}{l}\text { target } \\ \text { people who don't want } \\ \text { tochange }\end{array}\end{array}$

Besides bodat is also conceptualization of someone who is stupid and innocent. This concept can be seen in the following proverbs:

(9) Holong-holong bodat

'Affection like a monkey'

Meaning: someone who loves,other people in a way that wrong (stupid)

source $\longrightarrow$ target

bodat stupid/innocent people

\section{Proverbs about Birds}

Based on the results of the study, found the types of poultry used in the Toba Batak proverbs such as manuk, lali, leang-leang. The following proverbs are sourced from the poultry lexicon: (1) Andalu pasuk manuk ni halak butongan 'Dimple set aside other people's chickens the full one'; (2) Habang lali, dang habang tungko 'Fly an eagle, stumps don't fly'; (3) Unang loppa lali na habang 'Don't install eagles that fly'; (4) Habang so marhabong, songgop so marreatan 'Fly without wings, alight not have perch'; (5) Nang pe dibagasan sunuk Manuk Sabungan I, sai tong do martahuak 'Even if the cock is locked in cage, keep crowing too'; (6) Songon manuk na tarhiap 'Like a fan on a chicken'; (7) Unang gulut imput 
ni leang-leang 'Do not seize the tail of a swallowoverpass'.

\section{Manuk Sabungan (Rooster)}

Manuk sabungan (rooster) is a conceptualization of someone who is brave and good at fighting. This can be seen in the following proverbs:

(10) Nang pe dibagasan sunuk manuk sabungan i, sai tong do martahuak

'Even if the cock is locked in cage, keep crowing too'

Meaning: A brave man, everywhere he

source $\stackrel{\text { was about to show his cour- }}{\text { age }} \underset{\text { target }}{\longrightarrow}$ manuk sabungan
brave

\section{Lali (Eagle)}

The lexicon lali (eagle) is a conceptualization of someone who is not responsible. In the proverb below, lali (eagle) is conceptualized as someone who disappears after owing or committing a crime.

(11) Habang lali, dang habang tungko 'Fly an eagle, stumps don't fly'

Meaning: Even if someone disappears because of debt or deeds evil, but brother or his family did not particicipate disappear which be come person in charge

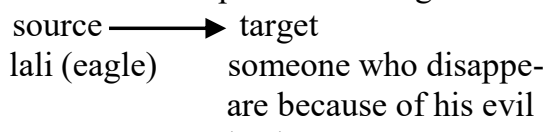
deeds

\section{Leang-leang (Swallow)}

Leang-leang (swallow-tailed) input is a conceptualization of something in vain. The following proverb is intended

(12) Unang gulut imput ni leang-leang 'Do not seize the tail of a swallowoverpass'

Meaning: Don't fight for something in

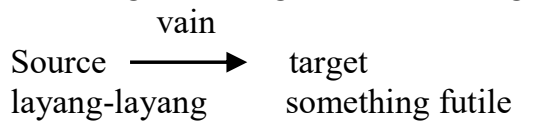

\section{Proverbs about Fish}

Toba Batak proverbs originating from fish are as much as $10 \%$. The lexicon used includes dengke, haruting and ihan. The following proverbs are referred to: (1) Ngali aek diingani dekke 'Cold water inhabited by fish'; (2) Songon haruting mangallang anakna 'Like cork fish that eat his son'; (3) Suhar songon lapoan ihan, husor songon lapoan manuk 'Fall like eating fish, upside down like eating chicken.

\section{Dekke (Fish)}

The dengke lexicon or ihan is a conceptualization of someone who likes the environment that is his culture:

(13) Ngali aek diingani dekke 'Cold water inhabited by fish' Meaning: People who are more happy live in an indigenous environment and the culture

$\begin{array}{ll}\text { source } \longrightarrow & \text { target } \\ \text { dekke (fish) } & \text { someone who happy } \\ & \text { to live in customary } \\ \text { environment }\end{array}$

\section{Haruting (Fish Cork)}

Haruting lexicon is a conceptualization of despotic leaders or leaders who do not pay attention to the lives of their subordinates and lavish the results of the efforts of their members

(14) Songon haruting mangallang anakna 'Like cork fish that eat his son' Meaning: A leader who lives in luxury from the results of members efforts he leads.

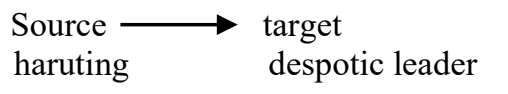

\section{Proverbs about Insects}

Found as many as $13 \%$ of Toba Batak proverbs originating from insects. The lexicon include hutu, lanok and taharu Proverbs originating from the insect animal lexicon: (1) Sai dianggo lanok do na bau 'Always smelling a smelly fly'; (2) Manat sisigat hutu manat sisigat hata 'Be careful kuti seekers are more careful speaker'; (3) Solhot hutu, solhot do gomit 'Sticky fleas, sticky eggs'.

\section{Lanok (Flies)}

Lanok lexicon is a conceptualization of someone who behaves badly.

(15) Sai dianggo lanok do na bau 
'Always smelling a smelly fly'

Meaning: A place that is not always good visited by someone who not good

source $\longrightarrow$ target

lanok someone always looking for bad

things

\section{Proverbs about Amphibians}

Found one proverb Toba Batak originating from amphibians namely sibagur lexicon (frog). The following proverbs are sourced from amphibians:

\section{Sibagur (Frog)}

Sibagur is a conceptualization of someone who always leaves a problem.

(16) Songon parlange ni sibagur, tio tu jolo, litok tu pudi

'Like a frog swimming, clear to the front turbid back'

Meaning: Someone who is always leave problems in place he left behind

$\begin{array}{ll}\text { source } \longrightarrow & \text { target } \\ \text { sibagur } & \text { seseorang yang selalu } \\ & \text { meninggalkan masalah }\end{array}$

\section{Discussion}

Based on the results of the research, proverbs about animals can be grouped in five sources, namely proverbs originating from mammals, fish, poultry, insects and amphibians. The use of mammals is the dominant form that is as much as $47 \%$, which is dominated by pets such as horbo (buffalo) and lobbu (ox). The emergence of the horbo lexicon is caused by the social conditions of the Toba Batak people who work as majority farmers. This is in line with Krikmann (2007) in his research showing that the use of the name of the animal that is most often found in proverbs is animal that can be bred and animals that are domesticated

The use of animal metaphors in the Toba Batak proverb is used as a means of creativity of the writer in choosing and determining what concepts will be chosen and what conceptualizations will be carried out to strengthen the ideas, views or ideas that the author wants to convey (Nirmala, 2012; Lakof, 1992)

Mammals such as horbo (buffalo) are chosen to conceptualize tough-headed and hardworking leaders. In contrast to the Lombu (ox) which is described as arguing.

In the Batak Toba lexicon Asu (dog) proverb is described as faithful and is a valuable treasure that must be guarded. (Lakof \& Turner, 1989) In contrast to the Malay and Arabic proverbs that describe dogs as animals that are despicable, weak, evil and messy (Abdullah, 2001; Sameer, 2016).

Pig lexicon in the Toba Batak proverb is depicted as abject and dirty, bodily lexicon (monkey) is described as stupid, lexicon babiat (tiger) is described as a brave leader and mouse lexicon is described as weak (Lakof, 1989). Birds such as manuk sabungan (roosters) are described as brave, lali (eagles) are not responsible and leangleang (swallow as a picture of pointless things). Pisces animals (fish) such as haruting (cork fish) are depicted as cruel or despotic, and ihan or dekke (fish) are described as not wanting to change. Lanok (flies) animals are described as dirty and have bad character and sibagur (frogs) are described as rioters and like to leave problems.

The animal lexicon is used by writers as creativity to symbolize ideas, ideas and advice to readers. Generally used to describe the nature, character and character of a person. The intended nature and character can be positive and negative.

\section{CONCLUSION}

The results showed that there were 33 lexicon animals used in Toba Batak proverbs. The animal lexicon comprises $46 \%$ of mammals, $27 \%$ of birds, $14 \%$ of insects, $10 \%$ of fish and $1 \%$ of amphibians.

Animal conceptualization can be both negative and positive. Proverbs originating from mammals include babi (pigs), bodat (monkeys), bagudung (mice), lobbu (cattle) are negative conceptualizations, while babiat (tigers) and horbo are positive conceptualizations.

Proverbs originating from birds namely manuk sabungan are described positively while lali (eagle) and leang-leang (swallow) are depicted negative. Pisces animals including ihan (fish) 
and haruting (cork fish) are negative conceptualizations. Insect animals namely lanok (flies) and amphibians namely sibagur (frogs) are described negatively. The use of animal metaphors in the

\section{REFERENCES}

Abdullah, I. H. (2011). Analisis Kognitif Semantik Peribahasa Melayu Bersumber dari Anjing. GEMA Online Journal Of Language Studies, 11 (1): $125-141$.

Allwood, J. \& Gardenfors P. (1999). Cognitive Semantics: Meaning and Cognition. New York: John Benjamins Publishing Company.

Chairani, E. (2017). Kajian Kognitif Semantik Penggunaan Anggota Tubuh dalam Peribahasa Bahasa Indonesia. Tesis. Medan: Pascasarjana Unimed

Deli, N. (2014). Proses Kognitif dalam Ungkapan Metaforis. Jurnal Parole, 4 (1): 1-13.

Haula, B. \& Tajudin N. (2019). Konseptualisasi Metafora dalam Rubrik Opini Kompas: Kajian Semantik Kognitif. Jurnal Retorika, 12 (1): 2535.

Howell, S. R. (2000). Metaphor, Cognitive Models, Language. Mc.Master University Honeck.

Jaszczolt, K. M. (2002). Semantics and Pragmatics: Meaning in Language and Discourse. Edinburgh: Pearson Education.

Kinantik, K. P. (2019). Metafora Tumbuhan dalam Peribahasa Indonesia: Kajian Semantik Kognitif. Jurnal Belajar Bahasa, PSPBSI Univiversitas Muhammadiah Jember

Konvesces, Z. (2002). Methaphor: Practical Introduction. Newyork: Oxford University Press.

Lakoff, G. \& Johnson, M. (1980). Metaphors We Live By. Chicago: The University of Chicago Press.

Lakoff, G. (1992). The Contemporary Theory of Metaphor. Cambridge: University Press.

Lyons, J. (1995). Linguistic Semantics. New York: Cambridge University Press.

Mieder, W. (2004). Proverbs: A handbook. London: Greenwood Press.

Norrick, N. R. (1985). How Proverbs Mean? Semantic Studies in English Proverbs. Amsterdam: Mouton.
Toba Batak proverbs not only aims to convey ideas or ideas but can also describe the perceptions, experiences and daily life depictions of the Toba Batak people

Rahardian, E. (2018). Tinjauan Semantik Kognitif Terhadap Peribahasa Indonesia Bersumber dari Harimau. Makalah Disajikan dalam Seminar Hasil Penelitian Kebahasaan dan Kesusasteraan, Balai Bahasa Jawa Tengah, 22 November 2018.

Richard, P. (2013). A Proverb in Mind: The Cognitive Science of Proverbial. New Jersey London: University Of Cincinnati.

Saeed, J. I. (1997). Semantics. Malden: Blackwell Publisher Inc.

Sameer, I. H. (2016). A Cognitive Study of Certain Animals in English and Arabic Proverbs: A Comparative Study. International Journal of Language and Linguistics, 3(5): 133-143.

Sihombing, T.M. (1989). Jambar Hata Dongan Tu Ulaon Adat. Medan: Tulus Jaya

Silalahi, R. (2005). Metafora dalam Bahasa Batak Toba. Jurnal Logat, 1(2): 10-19

Sinaga, R. (2013). Umpasa, Umpama, dan Ungkapan dalam Bahasa Batak Toba. Jakarta: Penerbit Dian Utama.

Siregar, B. (2004) Metaphors of Governance in the Language of the Indonesian Pers. Jakarta: Unika Atmajaya.

Sudaryanto. (2008). Metode dan Aneka Teknik Analisis Bahasa: Pengantar Penelitian Wahana Kebudayaan Secara Linguistik. Yogyakarta: Duta Wacana University Press.

Tampubolon, J. F. (1998). Umpasa Batak Toba: Tinjauan Mimetic. Medan: Fakultas Sastra, Universitas Sumatera Utara

Usman, F. (2004). Metafora dalam Mantra Minangkabau. Tesis. Denpasar: PPs Universitas Udayana Denpasar. 